\title{
Social cohesion, social mix, and urban policies in the Netherlands
}

\author{
Ronald van Kempen · Gideon Bolt
}

Received: 30 July 2009/Accepted: 30 July 2009/Published online: 2 September 2009

(C) The Author(s) 2009. This article is published with open access at Springerlink.com

\begin{abstract}
Urban policy in the Netherlands has long been focused on improving disadvantaged urban districts. In the last 13 years policy has become particularly area-based. Here the spatial concentration of low-income households has been seen as a highly problematic issue. Because of this negative view of these concentrations, a housing mix in the problematic urban areas has been considered to be one of the most promising solutions. A housing mix would result in a social mix and more social cohesion within the district. Strikingly, numerous researchers point out that the social mix might not resolve the problems in those areas, while at the same time central and local government holds on to the idea of the mix. We give some background of urban policy in the Netherlands and focus on the relationship between social mix and social cohesion. After a brief review of the literature on this relationship, we give an account of recent Dutch urban policies, particularly on the role of social mix and social cohesion within them. This review yields some important inferences for future urban policies in the Netherlands and other West European countries.
\end{abstract}

Keywords Social mix $\cdot$ Social cohesion $\cdot$ Urban policy $\cdot$ The Netherlands

\section{Introduction}

There have always been, and always will be, deprived urban districts. But this sweeping assertion does not mean that such districts should be left alone. Governmental and other important bodies such as housing associations and private developers have always invested in problematic districts. Investments have been targeted at specific areas or at a limited number of problems. More recently, the tendency has been toward integrated policies targeting several problems at the same time. We can often find a combination of integrated and area-based policies (Andersen 2001; Van Kempen and Van Beckhoven 2006).

R. van Kempen $(\bowtie) \cdot$ G. Bolt

Department of Human Geography and Planning, Urban and Regional Research Centre Utrecht, Utrecht University, P.O. Box 80.115, 3508 TC Utrecht, The Netherlands

e-mail: r.vankempen@geo.uu.nl 
Some issues within area-based integrated policies invariably seem to be more crucial than others. In the last decade or so issues involving social mix and social cohesion have been prominent on many urban policy agendas. They often feature social mix and social cohesion as explicit targets. Moreover, these two concepts are considered to be related: better social mix increases social cohesion. This idea relates to an even broader issue: the relationship between physical measures and social effects.

There are some crucial problems, however. First: What kind of cohesion are we talking about? And is it really so useful to have social cohesion at the top of the policy agenda? Second: Is there a positive relationship between social mix and social cohesion? The main aim of this paper is to give insight into the relevance of both social mix and social cohesion for urban-policy initiatives in the Netherlands.

We first pay attention to the concept of social cohesion and show that different definitions are used, which creates problems when policy-makers use this concept. The section on social cohesion is followed by an overview of the empirical evidence on the link between social mix and social cohesion. After a brief overview of the role of a social mix in older urban policies in the Netherlands, the most recent Dutch policies (urban restructuring and the 40-districts policy) are analysed with a focus on the role of mixed districts and social cohesion. The conclusions are based on a document analysis of 31 municipal programmes and 31 district plans.

\section{The concept of social mix and social cohesion: definitions and some problematic issues}

Social cohesion is a difficult concept. In its most general meaning it refers to a kind of glue holding society together (Maloutas and Malouta 2004; see also Dekker 2006). According to the influential work of Kearns and Forrest (2000), social cohesion comprises shared norms and values, social solidarity, social control, social networks, and a feeling of belonging to each other through a common identity and a strong bonding with the place where one lives (see also Forrest and Kearns 2001). These dimensions are usually assumed to reinforce each other: whenever people have, for example, the same ideas about life (shared norms and values), the chance of making social contacts is greater and so the feeling of being part of a certain group or a particular neighbourhood or district is reinforced (see also Atkinson and Kintrea 2002). However, empirical research shows that not all dimensions of social cohesion are strongly interrelated and that, therefore, these dimensions cannot be considered to be interchangeable (Dekker and Bolt 2005). In fact, social cohesion cannot be seen as a single concept, but as a "domain of causally interrelated phenomena or as a class of causal models, in which some of the major dimensions of social cohesion occupy different theoretical positions with respect to one another as antecedent, intervening, or outcome variables" (Friedkin 2005, p. 409).

This complexity of the social cohesion concept may be one of the reasons that the term is often ill-defined in policy documents (Dekker 2006). According to Robinson (2005, p. 1415) the term is merely used as "an empty vessel into which the preoccupations of contemporary public policy were poured". He argues that the policy focus on social cohesion is a reflection of the collective diagnosis of policy-makers and urban scholars alike that we live in an era of a crumbling social order (see also Kearns and Forrest 2000). The preoccupation with social cohesion is especially prevalent in eras that are characterized by huge societal changes. It is no coincidence that classical sociologists like Durkheim and Tönnies emphasized the changes in the social fabric at a time that the Western world 
entered the age of industrialism (Dekker 2006). Likewise, the present concerns about social cohesion could be linked to the transition to the informational age (Forrest and Kearns 2001). However, for the British context, Robinson (2005) emphasizes the link with shifting attitudes to multiculturalism. He argues that community cohesion had hardly a place on urban policy agendas before the urban disturbances in the summer of 2001 in Bradford, Oldham and Burnley. The official reports and policy responses identified the spatial segregation of minority ethnic groups as the main underlying problem in these towns. This problem is linked to housing processes and specifically to the alleged self-segregation of South Asian households (Phillips 2006). This view is, for instance, expressed in the Cantle Report (Home Office 2001, p. 9): "The team was particularly struck by the depth of polarisation of our towns and cities (...) many communities operate on the basis of parallel lives. These lives often do not seem to touch at any point, let alone overlap and promote meaningful exchanges". This report is illustrative for the shift in the debate on ethnicity and housing in the UK. While the discussion in the past focused on combating racial inequality, the focus is more and more on stimulating social cohesion. The community cohesion agenda can be seen as a move away from valuing cultural diversity in favour of a policy that aims for assimilation (Harrison et al. 2005). The consequence of this is that ethnic differences are over-emphasized at the cost of socioeconomic differences and the root of the problems is one-sidedly connected to minority ethnic communities (Robinson 2005).

Other problematic aspects of the policy discourse on social cohesion are that the focus is often restricted to the level of the neighbourhood and that there is a lack of attention for possible negative aspects of social cohesion. The idea is that social cohesion is a bottom-up process: the quality of social integration at the neighbourhood level is the basis for social cohesion at higher scale levels (Forrest and Kearns 2001; Morrison 2003). However, social cohesion at the neighbourhood or district level is not necessarily positive. Strengthened social cohesion within neighbourhoods can lead to a situation in which a city consists of neighbourhoods that have little to do with each other: "A city can consist of socially cohesive but increasingly divided neighbourhoods. The stronger the ties which bind local communities, the greater may be the social, racial or religious conflict between them. The point is that social cohesion at neighbourhood level is by no means unambiguously a good thing" (Kearns and Forrest 2000, p. 1013; see also Maloutas and Malouta 2004). This links to the finding that for people on a low income in particular, a neighbourhood functions more as a source of bonding capital than as a platform for bridging capital (Burns et al. 2001). Bonding capital refers to the strong bonding between people that produces very little new information. This bonding is strong within a particular group, but easily leads to social fragmentation in the broader society. Bridging capital, in contrast, refers to weak ties that do provide information on the wider world, such as the availability of jobs (Granovetter 1973; Putnam 2000).

Within deprived urban areas a fundamental dilemma then arises. From the individual's viewpoint, a strong binding within a particular group can be positive; through it, one acquires social contacts, feelings of security and belonging, and the opportunity to exchange goods. But at the same time such a bond can lead, consciously or unconsciously, to the weakening of the bonds with the rest of the urban society (Healey 1997). A person may belong to a group of unemployed people who talk to each other, day in day out, bemoaning the hopelessness of their lives, but as a result no longer maintaining contacts with people who are in work, and so they get no information about any possible jobs for themselves (Healey 1997; Vranken 2001). Strong social cohesion of a particular kind might lead to weak economic opportunities. 


\section{The link between social mix and social cohesion}

There are many arguments underlying the desire of policy-makers to create mixed districts. Social mixing is expected to lead to a range of positive outcomes, like social cohesion, social mobility opportunities, more social capital, better services, less crime, an improved neighbourhood reputation, and more residential stability (see e.g., Arthurson 2002; Bolt and Van Kempen 2008; Kleinhans 2004; Tunstall 2003). Many of the associations between these outcomes and mixing policy lack a convincing empirical underpinning (Joseph et al. 2007), but for the purpose of this paper, we will only focus on the link between social mix and social cohesion. Before we do that, it should be mentioned that social mix is, like social cohesion, a somewhat problematic concept (Bolt and Van Kempen 2008; Goodchild and Cole 2001).

First, many different terms are used in policy documents that relate to social mix, like neighbourhood mix, social balance, residential mix and heterogeneity, but they are often not well defined. Second, it is not always clear on the basis of which categories (e.g., ethnic categories, poor, unemployed, anti-social people or a combination of these) mixing should take place. Thirdly, it is hardly ever clear at what spatial level mixing should take place. Should the mix take place within a block of flats, mixing rented and owner-occupied housing in the same block? Or should it be a mix within a street, with one block for the poor and another one, opposite or adjacent, for the middle-income households? Should we create homogeneous small neighbourhoods that together make a mixed district? Finally, it is hardly ever indicated what constitutes an optimal mix. In the past some cities (like Rotterdam and Frankfurt) have strived for a completely equal distribution of minority ethnic groups over the city as a whole, but it has never been clear why that would lead to an optimal mix in each neighbourhood (Bolt 2004). Galster (2007) argues that any country or city should be able to define a specific optimal mix, based on its specific context and policy objectives, but we do not know of any example in which this is actually done. In general, policy-makers are better able to define what an imbalanced population composition is than to indicate what the exact mix is that should be strived for (Goodchild and Cole 2001).

The widely held claim among policy-makers that social mix leads to social cohesion can be refuted on the basis of two types of empirical research. First, there is a highly quantitative research tradition in which the compositional characteristics of neighbourhoods are related to social cohesion. Using the nationwide Survey of English Housing (SEH), Kearns and Mason (2007) assessed the impact of tenure mix (as a proxy for social mix) on a variety of neighbourhood problems. A greater diversity of tenure was found to be associated with an increase in five of the 10 neighbourhood problems that respondents were asked to identify. Tenure mix is not associated with a reduction in any of the neighbourhood problems. Interestingly, the issue that was most strongly related to tenure mix was the incidence of problems with neighbours, which is an indication of the lack of social cohesion in mixed neighbourhoods.

This conclusion is, at least partly, supported by the study of Völker et al. (2007) on the basis of a dataset of over 1000 respondents in 168 Dutch neighbourhoods. They assessed the effect of both income and ethnic heterogeneity on two dimensions of social cohesion: sense of community and the number of neighbours in one's social network. They found that income heterogeneity has a negative effect on one's sense of community, but no effect on the number of neighbours in one's network. The reverse is true for ethnic heterogeneity: no effect on a sense of community, but a negative effect on the number of neighbours in the network. The influential research of Putnam (2007) in 50 different communities in the US gives even more reason to be pessimistic about the association between ethnic mix and 
social cohesion. He found that a higher ethnic heterogeneity is associated with a lower level of trust felt towards local politicians as well as fellow-residents. Furthermore, ethnic heterogeneity negatively affects the size of social networks and leads to a lowered propensity to participate in neighbourhood or volunteer organizations. In contrast to both contact and conflict theories, it is found that there is no negative correlation between ingroup trust and out-group trust or between bridging and bonding capital. Ethnic heterogeneity turns out to have a negative effect on both types of trust and capital: "Diversity seems to trigger not in-group/out-group division, but anomie or social isolation. In colloquial language, people living in ethnically diverse settings appear to 'hunker down'that is, to pull in like a turtle" (Putnam 2007, p. 149).

The second strand of literature that refutes the policy assumptions with regard to the link between mix and social cohesion consists of studies that evaluate social mixing policies. These studies may be either quantitative or qualitative and usually focus on only a few neighbourhoods. Van Bergeijk et al. (2008) asked over a thousand respondents in six urban restructuring areas whether they had witnessed an improvement or decline of social cohesion in the neighbourhood since the differentiation of the housing stock had taken place. Only in one neighbourhood did people speak in a positive sense of an evolving social cohesion. In four neighbourhoods, those who saw improvement were significantly outnumbered by people who thought that the social cohesion had declined. This finding is in line with the outcome of the study by Wittebrood and Van Dijk (2007). They compared the assessment of social cohesion in 24 restructured neighbourhoods with 24 comparable neighbourhoods in which restructuring (mix tenures) has not taken place (yet). Social cohesion turned out to have evolved more positively in the other neighbourhoods than in the restructuring neighbourhoods. ${ }^{1}$

Most studies on neighbourhood diversification examine the degree of social interaction between several groups within the neighbourhood (see Atkinson 2005; Joseph et al. 2007; Kleinhans 2004 for an overview). Many researchers have found that renters and owneroccupiers have totally different activity patterns and hardy any contact with each other (see, e.g., Jupp 1999; Van Beckhoven and Van Kempen 2003; Arthurson 2007). In the United States in particular it has been found that there is almost no interaction between different income groups in mixed neighbourhoods (see, e.g., Rosenbaum et al. 1998; Popkin et al. 2002). This leads to the conclusion that spatial proximity is not a sufficient condition for social interactions (Kleinhans 2004). Differences in lifestyle make it not very likely that people with different characteristics will develop social relationships. People like to live among people with similar characteristics (Van Ham and Feijten 2008). It is therefore no surprise that the quantitative studies described above showed that homogeneous neighbourhoods score better than heterogeneous neighbourhoods.

There are some indications, however, that social mix may work under certain circumstances. Interactions between income groups occur when there is a moderate degree of income heterogeneity (Brophy and Smith 1997; Rosenbaum et al. 1998). Apparently, mixing rich and poor people does not bring about positive social returns, but a mix of the very poor and moderately poor might work. Another condition under which social mix might work is when diversity is achieved at a very low scale, which is referred to as pepper

\footnotetext{
1 The study by Wittebrood and Van Dijk (2007) overcomes several of the limitations that are characteristic for most evaluation studies (see Kleinhans 2004). First, the study is not limited to just a few neighbourhoods. Second, a comparison is made with neighbourhoods where social mixing policies are not implemented. Third, the level of social cohesion is measured at two moments in time. Usually, evaluation studies are based on a survey at one point in time and rely on asking retrospective questions.
} 
potting in the British literature (Jupp 1999). ${ }^{2}$ The idea is that social interaction in the neighbourhood takes place mainly between people who live very close to each other. When building blocks within a mixed neighbourhood remain homogeneous, it is not to be expected that many interactions between different groups will occur. However, other authors warn that a large degree of heterogeneity at a low scale may have unwanted consequences, such as coolness or even tensions between neighbours (Gans 1961; Goodchild and Cole 2001; Kleinhans et al. 2007).

\section{Social mix in Dutch urban policy: a concise history}

The idea of mixed districts in the Netherlands goes back to the first years after the Second World War. At that time the idea of the district as a relevant entity for its inhabitants was prominent. However, the main mantra was not the idea of mixing groups but rather of mixing functions. By mixing different kinds of function, such as housing, work, amenities, and recreation, the inhabitants would have much of their activity pattern in the district and would not be obliged to leave the area for their activities (Van der Horst et al. 2002). There were also some notions in Dutch urban policy about the advantages of mixing social classes in order to reduce the inequalities between them. In the UK this issue was more prominent, however, probably because of more marked distinctions between the social classes (Goodchild and Cole 2001).

Already in the mid-1950s an influential Dutch sociologist, Van Doorn, wrote a strong critique of the idea that urban districts and neighbourhoods were important in the lives of people. He claimed that the focus on the neighbourhood or district was wrong as it ignored the fact that people had become more mobile, which meant that the inhabitants were focused less on their immediate surroundings. Activities and social contacts were taking place somewhere else, which meant that the idea of the neighbourhood or district as a social unit should be abandoned (Van Doorn 1955).

In the 1960s the idea of the district as a social unit, with all its functions and people mixed in a limited space, was replaced by the idea of functional separation. Housing, work, and transport were separated. No longer was the main aim to create a small society in the district but instead to facilitate "modern man" in modern urban life (Van der Horst et al. 2002). This meant that a lot of attention was paid to connections: to roads, railroads, and public transport. "Modern man" should be transported to all areas within the city or the city region and should not stay in the district or neighbourhood.

Interest in social life in the neighbourhood and district was reawakened in the 1970s and 1980s when large-scale urban renewal activities were undertaken in the deprived preWWII areas of the large Dutch cities. A residential mix was not an explicit target in this period, however. On the contrary, the pivotal motto was "Building for the Neighbourhood", which meant that new dwellings in principle had to be built for the present inhabitants of the neighbourhood. There was no idea of attracting people from outside in order to create a better mix in socioeconomic terms. The policy was later criticised precisely because of the focus on building for low-income households (Van der Meer 1996).

By the end of the 1980s a new housing policy had become dominant. The 1989 White Paper on Housing marked the switch to a market-oriented housing policy, which stated explicitly that, especially in the large cities, the (extensive) social-rented sector in the

\footnotetext{
${ }^{2}$ In the UK, several authors have pleaded for pepper potting, but the Netherlands has not witnessed such a strong plea (Kleinhans 2004).
} 
Netherlands should only provide accommodation for below-modal incomes (Ministry of Housing, Spatial Planning and the Environment 1989). The number of more expensive dwellings (mainly in the owner-occupied sector) should be increased, aimed at housing people with modal to high incomes, coaxing them to leave the social-rented stock.

The Dutch social-rented sector had always been a mixed sector, providing housing for all kinds of income groups. In contrast with the UK, for example, the processes of the residualisation of the social-rented stock were unknown at that time, precisely because the social-rented sector was attractive and accessible to groups other than the low-income. With the new housing policy, the mismatch of the housing market (that is, the fact that indeed many social-rented dwellings were not inhabited by the groups for which these dwellings were built) ${ }^{3}$ was considered as one of the principal problems of the Dutch housing market. There were no arguments behind the formulation of this new policy to create mixed districts or more social cohesion. The idea was basically one of money and availability: those with higher incomes could afford to move, leaving the less expensive dwellings vacant for low-income households. The switch in policy was however, immediately followed by warnings from almost all housing researchers in the Netherlands: the new policy would create homogeneous housing segments (residualisation) and thus also homogeneous districts in terms of income.

\subsection{Big Cities Policy (1994-) and Urban Restructuring Policy (1997-)}

In the 1990s the idea that the homogeneity of poor urban districts and neighbourhoods in terms of the low socioeconomic status of the population had to be countered gradually became more dominant. In 1994 the Big Cities Policy was implemented, concentrating on problematic urban districts in (finally) 31 Dutch cities. This was a broad policy, targeting not only physical issues but also featuring social and economic measures: "The national government and large cities together aim to develop urban centres that are safe, while also meeting the increasing demands of residents, businesses, institutes, visitors and tourists. The goal is to develop economically vital cities with high-grade locations for business and social cohesion." (International website of the Ministry of Housing, Spatial Planning and the Environment 2008a).

Within the Big Cities Policy each of the 31 cities had to draw up a Development Programme, which had to contain in measurable terms all the efforts and measures that would be put in place in order to improve the social, economic, and physical situation of selected problematic urban districts within these cities. ${ }^{4}$ All physical measures have been referred to as urban restructuring since 1997, when the White Paper on Urban Restructuring (Ministry of Housing, Spatial Planning and the Environment 1997) was published. The paper stated explicitly that a healthy future for cities could only be guaranteed by a differentiated population composition: homogeneous districts should be transformed into mixed areas, especially through the demolition of part of the social-rented stock and building of more expensive dwellings. Many cities, not only the 31 largest cities of the Netherlands, started with initiatives to put these ideas into practice. Districts built in the

\footnotetext{
3 There was also another side of this mismatch: the fact that households with low incomes lived in more expensive dwellings. The consequence of this was that the state had to pay housing allowances to these households.

4 The city governments could select their most problematic neighbourhoods and districts themselves.
} 
period 1945-1965 (the early post-WWII areas) became the particular target areas. This policy is still in place. Demolition and refurbishment projects take a long time, sometimes even 8-10 years. Consequently, between first thinking about mixed areas and achieving the final result, many changes may occur, such as a new urban and national government coming into office, a partly new population settling in the area, and the construction of new housing elsewhere. The long production period also means that a new urban policy can be started before the process of urban restructuring has finished. This is what has happened in the Netherlands (see next section).

Since 2001 the debate on the social mix changed in tone. Until then the debate and the policies had been conducted and expressed in socioeconomic terms. After 2001, the problems associated with spatial concentrations of minority ethnic groups were featured explicitly, for instance in the influential Memorandum of a commission that investigated the effectiveness of Dutch integration policy. Parallel to the development in the UK (Robinson 2005), there was a clear shift towards an assimilation discourse. Through the 1990s the residential segregation of minority ethnic groups had mainly been interpreted as an indication that there is ethnic inequality in the access to housing (Bolt and Van Kempen 2002). Since 2001, however, the focus has been more and more on the supposedly negative consequences of residential segregation on the integration of minority ethnic groups. In the Yearly Memorandum on Integration Policy (Ministry of Justice 2005, p. 19, own translation) it is stated that “... Concentration is especially disadvantageous for integration because it results in an accumulation of social problems which may eventuate in a state of affairs that is very hard to handle (...). Concentration is also disadvantageous because it makes the ethnic dividing lines more visible in a more concentrated way. That harms the image of ethnic minorities (...). Finally, concentration is particularly disadvantageous for the possibilities for meeting and contacts between persons from different origin groups (...) the diminishing contacts with native Dutch indirectly influence the social chances of ethnic minorities".

\subsection{The policy of strong urban districts in the Netherlands}

At the beginning of 2007, a new government was installed in the Netherlands. This coalition government of Christian and Social Democrats and a smaller Christian party seems to have placed social cohesion prominently on its main agenda: "Working together, living together', is the slogan of the new Dutch government. 'Living together' takes place to a significant extent in districts. The street, the district and the neighbourhood, in addition to people's homes and workplaces, form the environment in which daily life is lived. The quality of that living environment and the manner in which we interact within it therefore largely determines the quality of a society as a whole" (International website of the Ministry of Housing, Spatial Planning and the Environment 2008b).

One of the changes in the government structure, compared with earlier periods, was the appointment of a new Minister of Housing, Districts and Integration. This appointment can be seen as a clear reference to the idea that there is, or at least should be, a connection between physical issues (housing), space (districts), and social issues (integration).

In the spring of 2007, the Minister of Housing, Districts and Integration announced that her policy on district improvement would target only 40 districts in Dutch cities. This policy would be focused on transforming problematic urban districts into areas in which a diversity of people would like to live. In her first White Paper ("From Attention District to Strong District"; Ministry of Housing, Spatial Planning and the Environment 2007a), the 
new Minister stated clearly that, in the 40 areas she had selected for her new policy of creating (within a period of $8-10$ years) strong districts, ${ }^{5}$ the problems derived to a large extent from the population composition of these areas. At the start of the memorandum she states that the selected areas have an over-representation of deprived households. It is also stated that these areas have an over-representation of non-Western minority ethnic groups. Middle-income groups increasingly leave these areas, while at the same time low-income households and those with few chances on the labour market move in. This trend should be curtailed as it threatens the social mobility opportunities for low-income groups and ethnic minorities. In addition, it is important to recreate the social cement in a district; residents have to have the feeling of being at home in their districts and that they control their environment. One of the threats to social cohesion, according to the Minister, is the moving away of those who can afford to leave the district (Ministry of Housing, Spatial Planning and the Environment 2007a).

Clearly, the Minister had focused on the relationship between the social composition of an area and its lack of social cohesion (called here social cement). Social cohesion was operationalised as the feeling of being at home in and having control over the district one lives in. Interestingly, this analysis, set forth at the start of the Memorandum, is not elaborated further in the remainder. The terms "mixed districts" and "social cohesion" are not very prominent in the Minister's plan. It focuses on five broad themes: housing, labour, education, integration, and safety. New measures in these fields should resolve the difficulties in the problematic urban districts.

Nevertheless, the Minister seems to expect a lot from mixed districts. In an official letter to Parliament she stated that a differentiation of the housing stock would make it easier to stimulate contact between natives and non-natives. This should then increase the integration of minority ethnic groups in society (Ministry of Housing, Spatial Planning and the Environment 2007b, pp. 2/3). In the same letter she states that considerable attention is needed to create social cohesion in the problematic urban districts. Why these terms (cohesion and mixed districts) are more or less lost in the official Memorandum is far from clear.

\section{Analysis of municipal plans and programmes}

By means of a document analysis of municipal plans and programmes, we can assess how neighbourhoods with large concentrations of low-income and minority ethnic households are regarded by policy-makers at the local level. Furthermore, we can try to uncover how importantly social cohesion and social mix feature in the municipal plans. We have based our analysis on two types of documents. First, we examined the most recent Development Programme (for the period 2005-2009) that the 31 cities had to draw up a within the Big City Policy. Secondly, we have analysed 15 of the 40 District Plans. The Minister has asked the 18 municipalities in which one or more of the 40 selected areas are located to write detailed District Plans. ${ }^{6}$

\footnotetext{
5 Note the terminology with care: indeed, the policy is focused on urban districts, not on urban neighbourhoods. In general the districts comprise a number of urban neighbourhoods.

${ }^{6}$ We limited our analysis to the plans of the large cities of Amsterdam, The Hague, and Utrecht and the smaller cities of Deventer and Zaanstad.
} 
Table 1 What kinds of concentration are seen as problematic according to 31 development programmes?
Source: Bolt and Van Kempen 2008

\begin{tabular}{lcr}
\hline & Number & $\%$ \\
\hline Concentration is not seen as a problem & 2 & 6.5 \\
$\begin{array}{l}\text { Concentration is seen as problematic, but it is not } \\
\text { clear what kind of concentration is referred to }\end{array}$ & 7 & 22.6 \\
$\begin{array}{l}\text { Concentration is defined in socioeconomic terms } \\
\text { Concentration is defined in ethnic terms }\end{array}$ & 13 & 41.9 \\
$\begin{array}{l}\text { Concentration is defined in both ethnic and } \\
\text { socioeconomic terms }\end{array}$ & 5 & 12.9 \\
Total & 31 & 100 \\
\hline
\end{tabular}

\subsection{Development programmes ${ }^{7}$}

In 29 of these 31 Development Programmes the cities mentioned problems with spatial concentrations (Table 1). In most cases, reference is made to concentration on the basis of a low socioeconomic status (low-income households and/or unemployed). Only nine municipalities specify that ethnic concentrations are problematic. Although this is more than double compared to the previous Development Programmes (covering the time span 2000-2004), it seems to be a low number in view of the shifts in the national debates on integration described above. It seems likely that this relates to the lack of a possibility to steer ethnic composition directly (see Bolt, this issue), while diversity of income can be directly addressed by housing diversification.

The fact that housing diversification is seen as the main measure to address segregation might also be why almost all municipalities see the homogeneous housing stock in the urban districts as the single reason for the existence of concentrations of minority ethnic groups and/or low-income groups (Bolt and Van Kempen 2008). On the one hand this explanation is logical, but on the other hand it is striking that hardly any attention is given to housing preferences or housing allocation systems as factors that might be important for explaining these spatial concentrations. By focusing strictly on the housing stock as the stumbling block, the more or less automatic conclusion was that measures to reduce the homogeneity of the stock (i.e., demolition and new building) were the best solution (Bolt et al. 2008).

What is wrong with spatial concentrations of low-income households or minority ethnic groups? Interestingly, the most often mentioned negative effect of concentration is that is detrimental to social cohesion (Table 2). This view is described in 10 of the 31 Development Programmes, though in most cases the concept of social cohesion is not further operationalised. Therefore, it is not exactly clear how the cities see the relationship between the existence of concentrations of population groups and social cohesion (Bolt and Van Kempen 2008). Other negative effects that are regularly mentioned are 'problem cumulations', decline of liveability and fewer opportunities to make a housing career within the neighbourhood. It should be mentioned that many of the mentioned negative effects are not clearly specified. More often than not, terms like 'problem cumulation', 'increasing divisions' and 'low-income neighbourhoods' are not defined, let alone that it is made clear why these supposed effects should be seen as problematic. Only one

7 The analysis of the Development Programmes is described more extensively in Bolt and Van Kempen (2008). 
Table 2 Negative effects of concentration according to development programmes
Source: Bolt and Van Kempen (2008)

\begin{tabular}{llr}
\hline & Number & $\%$ \\
\hline Decline of social cohesion & 10 & 38.5 \\
Problem cumulation & 8 & 30.8 \\
Decline of liveability & 7 & 26.9 \\
Limitation of housing career options & 7 & 26.9 \\
Hampering integration of ethnic minorities & 4 & 15.4 \\
Development of 'low-income neighbourhoods' & 4 & 15.4 \\
Increasing divisions & 3 & 11.5 \\
Limiting social mobility opportunities & 1 & 3.8 \\
Deterioration of neighbourhood reputation & 1 & 3.8 \\
Decline of neighbourhood facilities & 1 & 3.8 \\
\hline
\end{tabular}

municipality indicates that concentration reduces the option for social mobility. This is in striking contrast with the emphasis of the most recent White Paper ("From Attention District to Strong District") on enlarging social mobility opportunities for low-income groups and ethnic minorities.

\subsection{The district plans}

The District Plans that were analysed have in common that they comprise a limited number of pages (on average about 30, including appendices). The texts are compact, with little analysis of the problems, scant attention for the relationship between the different problems in the districts, and not much analysis of causal mechanisms. Descriptions under the core themes generally have the character of no more than a summing up of problems, varying from dirt in the streets and too many cars on the sidewalks to long-term unemployment, increasing criminal activity, and the presence of multi-problem families. Rather quickly the District Plans turn into extensive lists of measures considered necessary to resolve the problems (see, e.g., Municipality of Amsterdam 2007e). These measures are often focused on one problem only, for example: the organisation of more sports events to combat the immobility of children; the organisation of Dutch language lessons for 100 parents to improve their chances on the labour market; the creation of $1000 \mathrm{~m}^{2}$ of new floor space to attract new small firms; the realisation of new forms of resident participation. The lists are often very long: for the Utrecht area of Kanaleneiland, for example, about 100 measures are named (Municipality of Utrecht 2007c). The important questions that arise with such a long list are of course whether there is any coherence between the measures, whether they work against each other, and whether capable people can be found to them carry out.

Should we expect to find attention for social cohesion in the District Plans? On the one hand, yes: first, because the issue of cohesion was prominent in the urban restructuring policy that is still in operation; and second, because the Minister stresses the importance of cohesion in her introductory text. On the other hand, perhaps not: later in her Memorandum, the Minister does not present cohesion as a core issue in her policy.

With respect to the importance of social cohesion, different ways of dealing with it can be discerned in the District Plans. First, it is clear that in hardly any District Plans is the lack of social cohesion seen as the single most pressing issue in the area. In three of the 15 Plans, the concept of social cohesion does not even appear at all (Municipality of Amsterdam 2007d; Municipality of The Hague 2007c; Municipality of Deventer 2007). Only in one plan, that for the Amsterdam District of Osdorp Midden, is social cohesion 
taken seriously. Here it is stated that the lack of social cohesion is the most pressing problem in the area (Municipality of Amsterdam 2007f). The authors of the report also state that this lack of social cohesion has a negative effect on the individual's quality of life and on communal living. The lack of cohesion leads to a lack of attention for the living environment and fellow district residents, to a lack of social control, and to a lack of mutual trust. Surprisingly, the perception of the overriding importance of the social cohesion problem does not lead to many measures to improve it.

In some of the plans, however, the lack of social cohesion is seen as one of the two most pressing issues. For example, in the Utrecht post-WWII area of Kanaleneiland, enhanced social cohesion is a major goal, together with a decrease in criminal activities and disruptive behaviour (Municipality of Utrecht 2007c). In Transvaal, a pre-WWII area in The Hague, creating strong social cohesion appears as the first mission ${ }^{8}$ (followed by a diversity of amenities and a flourishing neighbourhood economy) (Municipality of The Hague 2007a).

In some plans, social cohesion is seen as one of many goals of future policy (see, e.g., Municipality of Utrecht 2007a, b; Municipality of Amsterdam 2007a, c, h, i). Stronger social cohesion is considered necessary, together with more perspectives for children under 12 , less criminality, an increased feeling of security, improvement of the labour market position, less poverty, fewer school dropouts, higher quality of the district, and an improvement in the health situation of local inhabitants.

In most cases no clear rationale is given why social cohesion should be one of the goals. There is no clear analysis of the implications of a lack of social cohesion. However, in some cases this analysis is there, but in a rudimentary form. In Kanaleneiland (Utrecht), for example, it is stated that there is little contact between neighbours, which is at least partly a result of the diversity of the population in terms of lifestyle. As a consequence of this lack of cohesion, people do not correct each other and do not feel responsible for the neighbourhood or district. This situation leaves room for disruptive social behaviour to develop unchecked (Municipality of Utrecht 2007c).

Sometimes measures to improve aspects of social cohesion are mentioned without a clear statement that cohesion should be improved or without any indication of the possible success of such a measure. For example it is stated that meeting places should be created to facilitate meetings between different groups (Municipality of Zaanstad 2007). This may appear logical, but it is not clear how creating such meeting places would lead to more or better contacts between the members of different groups. In one of the Amsterdam areas, the school should become a focal point in neighbourhood life (Municipality of Amsterdam 2007a), but it is unclear if and how this could work. Elsewhere, sports facilities are said to increase social cohesion (or integration) and neighbourhood bonding (Municipality of Amsterdam 2007c).

\subsection{Mixed districts in the new urban policy}

How do the District Plans deal with the issue of mixed districts? Most plans state clearly that the housing stock is homogeneous (i.e., too many social-rented dwellings). In many plans this assertion is followed by the statement that this hinders households' opportunities of a housing career in their own district (e.g., Municipality of Utrecht 2007a). More diversity in the housing stock gives opportunities for higher-income households to make a

\footnotetext{
${ }^{8}$ But although the overriding importance of social cohesion is mentioned on the first page of the District Plan, the concept is not elaborated elsewhere in the Plan.
} 
housing career in the district or may attract new households from outside the neighbourhood (Municipality of Amsterdam 2007b; Municipality of The Hague 2007a, b). The transformation from districts dominated by social-rented dwellings to areas with more expensive alternatives is therefore deemed necessary. The policy of urban restructuring that started in 1997 (see above) was more focused than the present policy on attracting new inhabitants from outside the district. The focus is now more on creating more housing career opportunities for present inhabitants, which probably reflects the view that attracting new households (i.e., middle-income households) to areas with a poor reputation can be difficult.

The monotony of the housing stock is not always described in terms of tenure and price. The Municipality of Zaanstad (2007) states for its designated problematic area that people who make a career on the labour market cannot make a housing career in the district because of the lack of single-family dwellings in the area. In some cases it is the small size of the dwellings that is considered a problem. Many of the dwellings in the housing stock are small and inexpensive. The biggest problem in the district is poverty (Municipality of Amsterdam 2007a); many of these small dwellings are inhabited by relatively large families ${ }^{9}$ (Municipality of Amsterdam 2007e). The ensuing crowding causes a lot of pressure on public spaces in the district (Municipality of The Hague 2007b).

As in the case of social cohesion, different ways of dealing with the concept of mixed districts and its relationship with social cohesion can also be found in the District Plans:

- Creating mixed districts is not always the most important goal. In the 1997 White Paper on Urban Restructuring, the differentiation of the urban housing stock was clearly seen as the single most important policy goal. That is no longer the case in many of the present District Plans. The idea of a mixed district functions either as only one of the goals of the new urban policy or as one of the means of creating a better district. Several District Plans make it clear that the emphasis on creating mixed districts has not been abandoned. Nonetheless, it is not mentioned as a central issue in the present urban policy because the previous policy of urban restructuring is still in operation. In many District Plans the new urban policy is probably seen as an (in most cases nonphysical) addition to district improvement (see, e.g., Municipality of Amsterdam 2007b, c, e, f, g).

- Sometimes creating mixed districts is seen as one of the prominent goals. In some instances even percentages are mentioned. This is the case for the Overvecht area in Utrecht, where the aim is to decrease the share of social-rented dwellings from 75 to 65 per cent in the next 8-10 years (Municipality of Utrecht 2007a). It is also the case in another Utrecht district, Kanaleneiland, where in the same period the share should drop from 68 to 55 per cent (Municipality of Utrecht 2007c). In the Transvaal area of The Hague, 3,000 of the 6,033 dwellings will be demolished to make room for a more differentiated supply of 1,600 dwellings (Municipality of The Hague 2007a). ${ }^{10}$ That is not to say that the rationale underlying the foreseen change in the housing stock is always clearly stated. ${ }^{11}$

\footnotetext{
9 These large families are almost always non-native families, notably Moroccans and Turks. Interestingly, this ethnic aspect is often not mentioned.

${ }^{10}$ It is clear from these numbers that a significant number of households have to leave the area, not only because the supply of inexpensive dwellings will be diminished, but also because the total number of dwellings is decreasing.

11 Also no justification for the numbers of units to be demolished is given.
} 
- In many cases there is a clear intention to create mixed districts. The increasing possibility of making a housing career is sometimes, but not always, accompanied by the idea that higher-income households should be attracted to the district (Municipality of Utrecht 2007a, c; Municipality of Amsterdam 2007j). In the Amsterdam area of Overtoomse Veld, almost 100 per cent of the housing stock consists of social-rented dwellings, which results in an area accommodating poorly educated, unemployed people and featuring criminality and the disappearance of social mechanisms, which then feeds radicalisation tendencies (Municipality of Amsterdam 2007g). Sometimes the results are already very clear: it is stated that the expected decline in the number of unemployed people in the South Eastern part of Amsterdam will be the consequence of the increasing differentiation of the housing stock (Municipality of Amsterdam 2007c). ${ }^{12}$ The reasoning underlying the creation of mixed districts cannot always be found. Sometimes only vague arguments appear in the district plans. Rebecca Tunstall's observation for the UK may also hold for the situation in the Netherlands: "Support for mixed tenure has become so widespread and unquestioning that rationales are not always explicit and can be somewhat intangible" (Tunstall 2003, p. 156).

- In some cases there is clearly no need to create mixed districts. This is the case in the Utrecht districts of Zuilen and Ondiep, where there is clearly no need for more differentiation (Municipality of Utrecht $2007 \mathrm{~b}$, d). There is already a mix of social and private-rented and owner-occupied dwellings.

The authors of the District Plans sometimes seem to struggle with the issue of diversity in their districts. The District Plan for the Schilderswijk, a pre-WWII area in The Hague, (Municipality of The Hague 2007b) is an interesting example. This area was radically renewed physically in the 1980s. On page 14 of the District Plan it is stated that the monotone socioeconomic composition of the population (i.e., a majority of low-income households) is detrimental to the strength of the neighbourhood ('strength' is not further specified). And that within the population there is also a wide variety of cultures (i.e., many minority ethnic groups). Within these groups there is extensive cohesion, but people from different groups hardly meet; there is also a societal climate of distrust towards some population groups (the authors probably mean that natives do not like people from minority ethnic groups). Interestingly, a few paragraphs further on the same page it is stated that despite the large variety of cultures and lifestyles, the inhabitants of the district are able to live peacefully together. Many people who live in the area like it and are even proud of it. There should be more and better community centres and festivals to facilitate meetings between groups.

This example teaches us that, on the one hand, diversity is alright or at least unproblematic, but on the other hand contacts between groups ought to be better. Why closer contacts should be a goal is not made clear. What is also apparent from this brief description is that a concentration of low-income households is probably seen as more problematic than a mix of very different cultural groups.

\section{Conclusion}

In this paper we have focused on the role of social cohesion and mixed neighbourhoods in urban policies in the Netherlands. A main conclusion should be that social cohesion is not

12 In the same District Plan it is stated that this change probably means that the unemployed have moved to another area: the problem of unemployment is thus not solved. 
the most pressing issue in present-day Dutch urban policies. Only for some of the problematic districts in Dutch cities is the lack of social cohesion seen as the main issue. In most neighbourhoods the lack of cohesion appears as just one of the issues. Housing, safety, education, labour, and integration are generally seen as far more important. When social cohesion is mentioned in local policies, it is often not clear what kind or type or aspect of social cohesion is the most problematic or important. In none of the district plans is the concept of social cohesion analysed or elaborated. This deficiency can be problematic for policy, because if nobody knows exactly what should be improved, policy failure seems almost inevitable.

How does the role of the social mix feature in the new policies? Apparently nobody seems to have doubts about the positive effects of a social mix. In all the plans, the creation of more housing differentiation in the urban districts is taken for granted, continued as it is or even intensified. The main underlying motive is not the idea of a link between a social mix and social cohesion. Rather, it is to create opportunities for a housing career for middle-income households already living in the neighbourhood and in many cases (but not always) to create opportunities for new middle-class households. Why social mix is a "good thing" is in many instances not clear. Social mix has become a kind of mantra and policy-makers seem averse to questioning it.

The results of the study show that policies at the local level are not fully in line with the national discourse. More than what one would expect on the basis of local plans, the national government puts much emphasis on social cohesion and on the ethnic dimension of segregation. A simple explanation for the fact that social cohesion is not stressed in many district plans is that the attention for social cohesion in the Minister's White Paper seems only coincidental. When a Minister writes a Memorandum and identifies a number of core issues (in this case, housing, labour, education, integration, and safety) and then asks the local governments to produce district plans, it is not surprising that the cities will also focus on these core issues. Otherwise the Minister might think that a plan was incomplete and refrain from giving it her approval. So in most of the district plans we do indeed see a focus on the core items of the Minister's Memorandum. This explanation for the lack of emphasis on social cohesion is further grounded in the fact that social cohesion was stressed much more in the Development Programmes that were written just a few years before the district plans. In these programmes a crumbling social cohesion was the most frequently mentioned negative effect of concentration.

Another reason why social cohesion is not so prominent in the district plans may be that the concept is difficult to operationalise. None of the municipalities had been able to make it very clear how social cohesion is exactly defined. Thus, it is very hard to translate the goal of improving social cohesion into concrete measures. Finally, the discourse on social cohesion has some assimilationist and desegregationist overtones and can be partly seen as a reaction to concerns among the public about the increasing ethnic diversity, especially since 9/11. The debate has special relevance at the national level, as it is an issue that plays an important role in national elections. At the local level, there are no real options to desegregate ethnic minorities, which makes the whole idea of creating more cohesion by means of more ethnic mix less relevant. This probably also explains why municipalities focus more on the disadvantages of poverty concentration than on the disadvantages of ethnic concentration.

This paper has revealed some differences between policy discourses at the local and the national level. At the same time, it underlines the wide gap between the high policy expectations about social mix and the scientific evidence that does not support mixing policies at all. Several evaluation studies have shown that differentiation of the housing 
stock has led to a decline of social cohesion, at least in the short run. The lack of bridging ties in mixed neighbourhoods should have come as no surprise. As Herbert Gans already emphasized back in 1961, spatial proximity usually leads to interaction only when people have a similar background and/or shared interests. Yet the mixing idea apparently retains its strong intuitive appeal, despite the fact that researchers have been warning of unrealistic expectations for half a century (Gans 1961).

Apart from that, it should be stressed that the interests of local actors are not always in line with the interest of residents. Most research on the effects of social mixing deals with the interests and needs of the residents (Uitermark 2003). From this point of view, social mixing is a bad thing as it reduces the level of social cohesion within the targeted areas. This adds to the negative consequences for the social networks of those who are forced to leave due to urban restructuring. Actors, like local politicians and housing corporations, however, “. . . by their very nature, are concerned with the management of the neighbourhood and not (primarily) with the fate of individual households" (Uitermark 2003, p. 545). It is expected that the presence of more affluent households would increase the manageability of neighbourhoods, as it would lead to more social order (see also Goodchild and Cole 2001). Jupp (1999) adds that the liveability of neighbourhoods can also be expected to improve by tenure mix, because owners are likely to complain more often to local authorities and to participate in local associations. Unfortunately, these expectations also fail to be supported by empirical evidence (Joseph et al. 2007; Uitermark et al. 2007).

Despite the critical remarks we have made about the present urban policies, we do not want to deny that there are also positive aspects. It is good to see that in urban policies, and definitely not only in the Netherlands, considerable attention is paid to all kinds of aspects of neighbourhood improvement. Although there is a clear lack of problem analysis in many cities, often no clear sign of creativity, and no courage to deviate from general ideas (mixing is good) or from ideas put forward at higher policy levels (who wants to go against the ideas of a Minister?), although there are in most cases seemingly too many unconnected actions, although the number of areas the policies focus on is almost always too limited, what is positive is that we have said goodbye to monotonous policies that focus only on physical or social measures.

Open Access This article is distributed under the terms of the Creative Commons Attribution Noncommercial License which permits any noncommercial use, distribution, and reproduction in any medium, provided the original author(s) and source are credited.

\section{References}

Andersen, H. T. (2001). The new urban politics of Europe: The area-based approach to regeneration policy. In H. T. Andersen \& R. van Kempen (Eds.), Governing European cities; social fragmentation, social exclusion and urban governance. Aldershot: Ashgate.

Arthurson, K. (2002). Creating inclusive communities through balancing social mix: A critical relationship or tenuous link? Urban Policy and Research, 20(3), 1-29.

Arthurson, K. (2007). Social mix and social interaction: Do residents living in different housing tenures mix? (Paper for the conference of the European Network for Housing Research, Rotterdam, 25-28 June 2007).

Atkinson, R. (2005). Neighbourhoods and the impact of social mix: Crime, tenure diversification and assisted mobility. CRN paper 29. University of Bristol: ESRC Centre for Neighbourhood Research.

Atkinson, R., \& Kintrea, K. (2002). 'Opportunities and despair, it's all in there', or, 'Every area has its problems': Everyday experiences of area effects. Glasgow: Department of Urban Studies, University of Glasgow. 
Bolt, G. (2004). Over spreidingsbeleid en drijfzand [On dispersal policy and quicksand]. Migrantenstudies, 20(2), 60-73.

Bolt, G., \& Van Kempen, R. (2002). Wonen in multiculturele steden [Living in multicultural cities]. The Hague: Ministry of Housing, Spatial Planning and the Environment.

Bolt, G., \& Van Kempen, R. (2008). De mantra van de mix: ideeën, idealen en de praktijk [The mantra of the mix: Ideas, ideals and practices]. Utrecht: Forum: Institute for Multicultural Development.

Bolt, G., Van Kempen, R., \& Van Ham, M. (2008). Minority ethnic groups in the Dutch housing market: Spatial segregation, relocation dynamics and housing policy. Urban Studies, 45(7), 1359-1384.

Brophy, P., \& Smith, R. (1997). Mixed income housing factors for success. CityScape, 3(2), 3-32.

Burns, D., Forrest, R., Flint, J., \& Kearns, A. (2001). Empowering communities: The impact of registered social landlords on social capital. Edinburgh: Scottish Homes.

Dekker, K. K. (2006). Governance as glue: Urban governance and social cohesion in post-WWII neighbourhoods in the Netherlands. Utrecht: Faculty of Geosciences.

Dekker, K., \& Bolt, G. (2005). Social cohesion in post-war estates in the Netherlands: Differences between socioeconomic and ethnic groups. Urban Studies, 42(13), 2447-2770.

Forrest, R., \& Kearns, A. (2001). Social cohesion, social capital and the neighbourhood. Urban Studies, 38(12), 2125-2143.

Friedkin, N. E. (2005). Social cohesion. Annual Review of Sociology, 30, 409-425.

Galster, G. (2007). Neighbourhood social mix as a goal for housing policy: A theoretical analysis. European Journal of Housing Policy, 7(1), 19-43.

Gans, H. J. (1961). The balanced community-homogeneity or heterogeneity in residential areas? Journal of the American Institute of Planners, 27(3), 176-184.

Goodchild, B., \& Cole, I. (2001). Social balance and mixed neighbourhoods in Britain since 1979: A review of discourse and practice in social housing. Environment \& Planning D: Society and Space, 19, $103-122$.

Granovetter, M. S. (1973). The strength of weak ties. American Journal of Sociology, 78(6), 1360-1380.

Harrison, M., Law, I., \& Phillips, D. (2005). Migrants, minorities and housing: Exclusion, discrimination and anti-discrimination in 15 member states of the European Union. Vienna: EUMC.

Healey, P. (1997). Social exclusion, neighbourhood life and governance capacity. In H. Vestergaard (Ed.), Housing in Europe (pp. 88-110). Horsholm: Danish Building Research Institute.

Home Office. (2001). Community cohesion: A report of the independent reviewing team. London: HMSO.

Joseph, M. L., Chaskin, R. J., \& Webber, H. S. (2007). The theoretical basis for addressing poverty through mixed-income development. Urban Affairs Review, 42(3), 369-409.

Jupp, B. (1999). Living together: Community life on mixed housing estates. London: Demos.

Kearns, A., \& Forrest, R. (2000). Social cohesion and multilevel urban governance. Urban Studies, 37(5/6), 995-1017.

Kearns, A., \& Mason, P. (2007). Mixed tenure communities and neighbourhood quality. Housing Studies, 22(5), 661-991.

Kleinhans, R. (2004). Social implications of housing diversification in urban renewal: A review of recent literature. Journal of Housing and the Built Environment, 19(4), 367-390.

Kleinhans, R., Priemus, H., \& Engbersen, G. (2007). Understanding social capital in recently restructured urban neighbourhoods: Two case studies in Rotterdam. Urban Studies, 44(5/6), 1069-1091.

Maloutas, T., \& Malouta, M. P. (2004). The glass menagerie of urban governance and social cohesion: Concepts and stakes/concepts as stakes. International Journal of Urban and Regional Research, 28(2), 449-465.

Ministry of Housing, Spatial Planning and the Environment. (1989). Volkshuisvesting in de Jaren Negentig [Housing in the 1990s]. The Hague: Ministry of Housing, Spatial Planning and the Environment.

Ministry of Housing, Spatial Planning and the Environment. (1997). Nota Stedelijke Vernieuwing. [Memorandum Urban renewal]. The Hague: Ministry of Housing, Spatial Planning and the Environment.

Ministry of Housing, Spatial Planning and the Environment. (2007a). Actieplan krachtwijken: van aandachtswijk naar krachtwijk [Action plan for strong districts: From attention district to strong district]. The Hague: Ministry of Housing, Spatial Planning and the Environment.

Ministry of Housing, Spatial Planning and the Environment. (2007b). Kabinetsreactie op het door de VROM-raad uitgebrachte advies 'Stad en Stijging [Reaction of the cabinet on the VROM-council advice on 'city and upward mobility']. The Hague: Ministry of Housing, Spatial Planning and the Environment.

Ministry of Housing, Spatial Planning and the Environment. (2008a). http://international.vrom.nl/ pagina.html?id=7336, checked on 14 February 2008.

Ministry of Housing, Spatial Planning and the Environment. (2008b). http://international.vrom.nl/ pagina.html?id=10712, checked on 14 February 2008. 
Ministry of Justice. (2005). Jaarnota integratiebeleid 2005 [Yearly memorandum on integration policy]. The Hague: Ministry of Justice.

Morrison, N. (2003). Neighbourhoods and social cohesion: Experiences from Europe. International Planning Studies, 8(2), 115-138.

Municipality of Amsterdam. (2007a). Wijkactieplan Indische Buurt [District Plan Indische Buurt]. Amsterdam: Municipality of Amsterdam.

Municipality of Amsterdam. (2007b). Kansrijk Amsterdam Noord [North Amsterdam: Full of chances]. Amsterdam: Municipality of Amsterdam.

Municipality of Amsterdam. (2007c). Krachtige mensen in een krachtige wijk! Investeren in kansen in de EGK-buurt in Amsterdam Zuidoost [Strong people in a strong neighbourhood: Investing in chances in the EGK-neighbourhood in Amsterdam Zuidoost]. Amsterdam: Municipality of Amsterdam.

Municipality of Amsterdam. (2007d). Wijkactieplan De Baarsjes: Prachtkansen voor een prachtige wijk [District plan De Baarsjes: Great chances for a great neighbourhood]. Amsterdam: Municipality of Amsterdam.

Municipality of Amsterdam. (2007e). Werk in uitvoering: naar een wijkactieplan Bos en Lommer! [Work in progress: Towards a district plan for Bos en Lommer]. Amsterdam: Municipality of Amsterdam.

Municipality of Amsterdam. (2007f). Wijkactieplan Osdorp Midden [District Plan Osdorp Midden]. Amsterdam: Municipality of Amsterdam.

Municipality of Amsterdam. (2007g). Buurtactieplan Overtoomse Veld [Neighbourhood Plan Overtoomse Veld]. Amsterdam: Municipality of Amsterdam.

Municipality of Amsterdam. (2007h). Buurtactieplan Geuzenveld [Neighbourhood Plan Geuzenveld]. Amsterdam: Municipality of Amsterdam.

Municipality of Amsterdam. (2007i). Buurtactieplan Slotermeer [Neighbourhood Plan Slotermeer]. Amsterdam: Municipality of Amsterdam.

Municipality of Amsterdam. (2007j). Buurtactieplan Transvaal [Neighbourhood Plan Transvaal]. Amsterdam: Municipality of Amsterdam.

Municipality of Deventer. (2007). Wijactieplan Rivierenwijk [District Plan Rivierenwijk]. Deventer: Municipality of Deventer.

Municipality of The Hague. (2007a). De nieuwe aanpak voor Transvaal; wijkactieplan [The new policy for Transvaal, district plan]. The Hague: Municipality of The Hague.

Municipality of The Hague. (2007b). Verdrag van de Schilderswijk; wijkactieplan [Treaty of the Schilderswijk, district plan]. The Hague: Municipality of The Hague.

Municipality of The Hague. (2007c). De nieuwe aanpak voor krachtwijk Stationsbuurt; wijkactieplan [The new policy for the strong neighbourhood of Stationsbuurt, district plan]. The Hague: Municipality of The Hague.

Municipality of Utrecht. (2007a). Doe mee in Overvecht: Wijkactieplan Overvecht [Participate in Overvecht: District plan Overvecht]. Utrecht: Municipality of Utrecht.

Municipality of Utrecht. (2007b). Wijkactieplan Zuilen (oost) [District Plan Zuilen (east)]. Utrecht: Municipality of Utrecht.

Municipality of Utrecht. (2007c). Kanaleneiland leert! Wijkactieplan Kanaleneiland [Kanaleneiland learns! District Plan Kanaleneiland]. Utrecht: Municipality of Utrecht.

Municipality of Utrecht. (2007d). Wijkactieplan Ondiep [District Plan Ondiep]. Utrecht: Municipality of Utrecht.

Municipality of Zaanstad. (2007). Wijkactieplan Poelenburg [District Plan Poelenburg]. Zaanstad: Municipality of Zaanstad.

Phillips, D. (2006). Parallel lives? Challenging discourses of British Muslim self-segregation. Environment and Planning D: Society and Space, 24(1), 25-40.

Popkin, S., Harris, J., \& Cunningham, M. (2002). Families in transition: A qualitative analysis of the MTO experience, final report. Washington DC: US Department of Housing and Urban Development.

Putnam, R. (2000). Bowling alone: The collapse and revival of American community. New York: Simon \& Schuster.

Putnam, R. D. (2007). E pluribus unum: Diversity, community in the twenty-first century. The 2006 Johan Skytte Prize lecture. Scandinavian Political Studies, 30(2), 137-174.

Robinson, D. (2005). The search for community cohesion: Key themes and dominant concepts of the public policy agenda. Urban Studies, 42(8), 1411-1427.

Rosenbaum, J., Stroh, L., \& Flynn, C. (1998). Lake Parc place: A study of mixed-income housing. Housing Policy Debate, 9(4), 703-772.

Tunstall, R. (2003). 'Mixed tenure' policy in the UK: Privatisation, pluralism or euphemism? Housing, Theory and Society, 20, 153-159. 
Uitermark, J. (2003). 'Social mixing' and the management of disadvantaged neighbourhoods: The Dutch policy of urban restructuring revisited. Urban Studies, 40(3), 531-549.

Uitermark, J., Duyvendak, J. W., \& Kleinhans, R. (2007). Gentrification as a governmental strategy: Social control and social cohesion in Hoogvliet, Rotterdam. Environment and Planning A, 39(1), 125-141.

Van Beckhoven, E., \& Van Kempen, R. (2003). Social effects of urban restructuring: A case study in Amsterdam and Utrecht, the Netherlands. Housing Studies, 18(6), 853-875.

Van Bergeijk, E., van Kokx, A., Bolt, G., \& Van Kempen, R. (2008). Helpt herstructurering? Effecten van stedelijk herstructurering op wijken en bewoners [Does restructuring help? Effects of urban restructuring on neighbourhoods and residents]. Delft: Eburon.

Van der Horst, H., Kullberg, J., \& en Deben, L. (2002). Wat wijken maakt; de wording van functionele, sociale en expressieve kwaliteiten van Vreewijk, Zuidwijk en Ommoord [What makes neighbourhoods?]. Utrecht/The Hague: Nethur/DGW.

Van der Meer, C. E. (1996). Monitoring van buurten: Signalering en analyse van probleemcumulatie [Monitoring neighbourhoods: Signalling and analysis of problem cumulation]. Amsterdam: AME.

Van Doorn, J. A. A. (1955/1970). Wijk en stad: reële integratiekaders? [District and city: Realistic frames for integration?]. In S. Groenman \& H. De Jager (Eds.), Staalkaart der Nederlandse sociologie (pp. 231-253). Assen: Van Gorcum.

Van Ham, M., \& Feijten, P. (2008). Who wants to leave the neighbourhood? The effect on moving wishes of being different from the neighbourhood population. Environment and Planning A, 40(5), 1151-1170.

Van Kempen, R., \& Van Beckhoven, E. (2006). Urban governance and integrated policies. In R. van Kempen, A. Murie, T. Knorr-Siedow, \& I. Tosics (Eds.), Regenerating large housing estates in Europe: A guide to better practice (pp. 171-179). Utrecht: Urban and Regional research centre Utrecht, Utrecht University.

Völker, B., Flap, H., \& Lindenberg, S. (2007). When are neighbourhoods communities? Community in Dutch neighbourhoods. European Sociological Review, 23(1), 99-114.

Vranken, J. (2001). Unravelling the social strands of poverty: Differentiation, fragmentation, inequality, and exclusion. In H. T. Andersen \& R. Van Kempen (Eds.), Governing European cities: Social fragmentation, social exclusion and urban governance (pp. 71-92). Aldershot: Ashgate.

Wittebrood, K., \& Van Dijk, T. (2007). Aandacht voor de wijk-effecten van herstructurering op de leefbaarheid en de veiligheid [Focus on the neighbourhood-effects of urban restructuring on liveability and safety]. The Hague: SCP. 